\title{
Old English and Old Norwegian noun phrases with two attributive adjectives
}

\author{
Kristin Bech
}

\begin{abstract}
The topic of this paper is Old English and Old Norwegian noun phrases containing two attributive adjectives. An overview of the frequency of various word order constellations will be given, before we zoom in on one of them, namely the construction Adjective - Adjective - Noun, i.e. noun phrases in which two prenominal adjectives occur next to each other without a coordinating conjunction. Old English and Old Norwegian will be compared with respect to which adjectives occur in this position. The paper also includes an intermezzo, during which we investigate what happens to adjective position when a text is translated from present-day English into Old English.
\end{abstract}

\section{Introduction}

Old English and Old Norwegian are closely related early Germanic languages. Although a few centuries separate them with respect to the written record - Old Norwegian was not written down (in Latin script) until the thirteenth century, whereas the Old English written tradition started in the ninth century - they can nevertheless be said to represent approximately the same early Germanic stage. In fact, according to Lass (2000), who compared ten features in related Germanic languages with the purpose of placing them on a scale from less archaic to more archaic, Old Norse ${ }^{1}$ is slightly more archaic than Old English.

With the notable exception of Old (and Middle) English (Mitchell 1985 for basic taxonomy; Fischer 2000, 2001, 2006, 2012; Fischer and van der Wurff 2006; Haumann 2003, 2010; Pysz 2007, 2009), noun phrase structure in early Germanic languages is an under-researched area, especially in a cross-linguistic perspective. ${ }^{2}$ Claims about

1 I.e. Old Norwegian and Old Icelandic. Lass mentions Old Icelandic, not Old Norse, but we can assume that Old Norwegian belongs there as well. Old Icelandic and Old Norse are sometimes - erroneously used as synonyms.

2 The situation can be expected to be remedied in the next few years. The project 'Constraints on syntactic variation: noun phrases in early Germanic languages', funded by the Research Council of Norway, runs from September 2017 to August 2020. 
adjective position in Old Norse, stemming from Nygaard (1906) and Ringdal (1918), have been repeated in the century since (e.g. Valfells and Cathey 1981; Haugen 1995; Faarlund 2004), but as received wisdom rather than as possible research topics. As regards Old English, Fischer and Haumann have taken different positions, with Fischer arguing that there is a connection between adjective position on the one hand, and definiteness, declension and linear iconicity on the other (see e.g. Fischer 2000, p. 170; 2012, p. 252), whereas Haumann's stance is that adjective position 'follows exclusively from interpretive and functional differences' (2010, p. 54). Pysz's (2009) main concern is to account for the observed variation within a Chomskyan generative framework. Their suggestions will be discussed in future papers. The purpose of this paper is to give an empirical overview of adjective position in Old English and Old Norwegian noun phrases containing two attributive adjectives. ${ }^{3}$

Noun phrases containing one adjective are generally common in the old languages, ${ }^{4}$ but unlike the present-day languages, the old languages did not favour clusters of adjectives within the noun phrase; noun phrases with two adjectives are not particularly frequent, as we shall see, and more than two adjectives are rare within a noun phrase (see also Pysz 2009, p. 29). In present-day English and Norwegian, adjectives can easily be stacked, but it happens in a certain order, depending on the semantic properties of the adjective (see e.g. Quirk et al. 1985, p. 1337ff; Faarlund et al. 1997, p. 407-410). For example, non-gradable intensifiers occur before gradable adjectives, which occur before participles and colour adjectives, which occur before nationality adjectives. Hence, example (1) is perfectly fine, whereas (2) would be odd. Furthermore, postnominal adjectives are rare in the present-day languages; notable exceptions are set phrases, often loans, as in (3), phrases in which the head is an indefinite pronoun, such as (4), and phrases with modified adjectives, such as $(5)^{5}$ (Quirk et al. 1985, p. 1293 f.).

(1) a certain intelligent retired Norwegian professor

(2) a certain Norwegian retired intelligent professor

(3) The professor emeritus mostly lived off spaghetti bolognese in his retirement.

(4) somebody nice

(5) a mistake typical of absent-minded professors

3 One of Fischer's $(2000,2001,2006,2012)$ main points is that postnominal adjectives are 'functionally predicative' even when they are not in a predicative construction with a copula. I will not consider that proposal here; in this study I have regarded as attributive all adjectives that are annotated as modifying a head noun.

4 A simple query for noun phrases containing one adjective gave 42,291 hits in the Old English corpus and 5,048 in the Old Norwegian corpus - compare with the numbers in Table 1.

5 Norwegian does not have an equivalent of somebody nice, and as regards example (5), the construction is marginally possible in Norwegian: en feil typisk for distré professorer, but Norwegian would prefer to use a relative clause instead: en feil som er typisk for distré professorer. 
Old English and Old Norwegian allowed postnominal adjectives to a much greater extent, including descriptive adjectives. In other words, the present-day languages differ quite considerably from the early languages with respect to adjectives in noun phrases, and this paper describes and discusses some of the old patterns.

\section{Method}

The data is taken from two corpora, the York-Toronto-Helsinki Parsed Corpus of Old English Prose (YCOE, Taylor et al. 2003), and the Menotec corpus of Old Norwegian, hosted by the INESS infrastructure (Rosén et al. 2012). YCOE contains c. 1.5 million words in 100 texts of different genres from both early and late Old English (c. 800-1100). Menotec is a much smaller corpus, consisting of c. 214,000 words in four thirteenth century texts of different genres. These are The Old Norwegian homily book, The legendary saga of St. Olaf, Magnus Lagabøte's national law code, and Strengleikar 'stringed instruments', a chivalric saga adapted from Old French. Hence the question arises as to whether data from these corpora can be compared at all. I will argue that they can, for the reason that noun phrases containing attributive adjectives are generally frequent. Consequently, even a small corpus can be expected to yield general patterns. It will also become clear that Old English and Old Norwegian are in many respects quite similar as concerns noun phrase structure, which is what we would expect in two closely related languages. In other words, in terms of the data distribution, the situation is reassuring with respect to comparability. However, as in all corpus work, we nevertheless proceed with caution, keeping an eye out for possible genre differences, especially since the range of genres is much wider in YCOE than in Menotec.

I searched for all noun phrases containing two attributive adjectives. ${ }^{6}$ This was done by means of a number of queries, which also differ depending on the corpus, since YCOE annotates phrase structure in the Penn Treebank format, whereas Menotec annotates dependency structure. It was therefore a challenge to write the queries in such a way that they would yield comparable patterns for each category in the two languages. Consequently, I started out with relatively general queries, studied the results, and then narrowed the queries gradually. The different ordering possibilities are presented in Section 3. Note that this study is intended as an overview for the purpose of a general comparison of Old English and Old Norwegian, hence there are some distinctions that have not been made. For example, I have not distinguished between strong and weak adjectives, or between noun phrases with or without determiners. Some of the complexities are commented on in connection with each pattern, as the examples chosen for illustration are usually the most 'bare' examples.

6 Note that adjectival participles have not been included. 


\section{General overview of ordering possibilities}

Table 1 shows the results for Old English and Old Norwegian. The two languages are similar in the sense that all the patterns are possible, and they are also fairly similar with respect to the overall distribution. The most common patterns are A-A-N and A-N-and-A in both languages, accounting for $64.5 \%$ of the instances in Old English and $56.1 \%$ of the instances in Old Norwegian. Old Norwegian seems to favour explicit postnominal coordination more than Old English does, while Old English to a greater extent flanks the adjectives (A-N-A) (but see comments below).

\begin{tabular}{lrrrr}
\hline & \multicolumn{2}{c}{ Old English } & \multicolumn{2}{c}{ Old Norwegian } \\
& $\#$ & $\%$ & $\#$ & $\%$ \\
\hline A-A-N & 296 & 29.5 & 51 & 26.0 \\
A-N-A & 108 & 10.8 & 9 & 4.6 \\
N-A-A & 2 & 0.2 & 11 & 5.6 \\
A- and-A-N & 214 & 21.3 & 43 & 21.9 \\
A-N-and-A & 351 & 35.0 & 59 & 30.1 \\
N-A-and-A & 33 & 3.3 & 23 & 11.7 \\
\hline Total & 1004 & 100.1 & 196 & 99.9 \\
\hline
\end{tabular}

Table 1: Distribution of adjectives in noun phrases with two adjectives in Old English and Old Norwegian

Examples of the various constellations are given in (6)-(11), with Old English in the $a$ examples and Old Norwegian in the $b$ examples. ${ }^{7}$

\subsection{Patterns without conjunction}

\section{A-A-N}

(6) a. ealdum leasum spellum

(coboeth: 35.98.25.1907) old false tales 'old false tales'

b. einn ricr lenndr maðr (strleik: 2191) a rich landholding man 'a rich landholding man'

The A-A-N pattern, which is the focus of the present paper, will be considered in greater detail in Section 5.

7 For readability, Old Norwegian $\langle\mathrm{v}\rangle$ and $\langle\mathrm{f}\rangle$ have been normalized to $\langle\mathrm{u}\rangle$ and $\langle\mathrm{s}\rangle$. For example, miclu in example (7) reads miclv in the corpus. The source for each example is provided with the codes used in the corpora. 
A-N-A

(7) a. medmicle nose pynne

(cobede: 13.144.14.1391)

moderate nose thin

'moderate thin nose'

b. miclu lofte steinpildu

(strleik: 2191)

large loft stone-tiled

'large stone-tiled loft'

Whereas the modern languages would place the adjectives prenominally, the old languages could easily postpone one of them, either with (A-N-and-A) or without (A$\mathrm{N}-\mathrm{A}$ ) a conjunction. The A-N-A pattern is more frequent in Old English than in Old Norwegian, but here it should be noted that almost half of the Old English occurrences are from two medical handbooks, which use certain constructions to describe the ingredients needed in the various recipes for treatment. If these texts are removed from the corpus, A-N-A is still more frequent in Old English than in Old Norwegian, but the difference is much less pronounced. We will shortly consider the A-A-N pattern in some detail, and it will then become clear that although both languages allowed two prenominal adjectives, there were restrictions on which adjective types could occur together in prenominal position. In other words, there was a reason for the postponement of some adjectives.

N-A-A

(8) a. wingeardes twigu ufeweard merwe

(colaece: 12.1.5.2273) vine twig upper tender

'a vine twig of which the upper part is tender'

b. systir samfæðra skilgeten

sister same-father.ADJ trueborn

'sister, trueborn of the same father'

Noun phrases which contain two postnominal adjectives that are not linked by a coordinating conjunction are rare, especially in Old English, and the few examples that exist are formulaic expressions. All except one of the Old Norwegian examples are from Magnus Lagabøte's national law code.

\subsection{Patterns with conjunction}

\section{A-and-A-N}

(9) a. torhtum \& swutolum wordum

(cogregdC: 36.175.2.2130) clear and plain words

'clear and plain words' 
b. margar oc rikar giaver

(strleik: 2017)

large and rich gifts

'large and rich gifts'

The A-and-A-N category also includes noun phrases in which a determiner precedes the first adjective or both adjectives. This leads to some issues concerning the interpretation of the data, which will be discussed below.

A-N-and-A

(10) a. grimlicre stefne ond ladlicre

(comart3: Au25,A.9.1538)

fierce voice and unpleasant

'fierce and unpleasant voice'

b. agiætleg takn oc fagrleg

(olavssaga: 2644)

excellent sign and beauteous

'excellent and beauteous sign'

As regards this pattern, Old English and Old Norwegian are quite similar in terms of distribution, and this is perhaps a construction that we typically associate with Old English and Old Norse. Here as well, a determiner may precede one or both adjectives, cf. discussion below.

\section{$\mathrm{N}-\mathrm{A}$-and-A}

(11) a. ða maðmfatu gyldene and sylfrene

(cocathom2: 33:252.100.5621)

the costly vessels golden and silvern

'the costly vessels of gold and silver'

b. maðr spakr oc fastnæmr

(olavssaga: 191)

man wise and faithful

'a wise and faithful man'

In this construction, a noun is followed by two coordinated adjectives. For the purposes of this paper I have only considered noun phrases with two adjectives. Although they are infrequent, constructions with more than two postnominal adjectives exist, especially in Old Norwegian, it seems. This could be due to the genres included. For example, one of the texts in the Old Norwegian corpus is the chivalric saga Strengleikar. Hence, we get descriptions like the ones in (12) and (13), which serve to flavour the story.

(12) einn riddare curteis oc vaskr oc vapndiarfr (strleik: 2433) a knight courtly and able and weapon-brave 'a courtly and able knight, brave with weapons' 
grimm kona oc drambsom illmalog oc ovundsiuk (strleik: 424) grim woman and arrogant ill-spoken and jealous

'a grim, arrogant, ill-spoken and jealous woman'

It was mentioned above that as regards the patterns with conjunction, a determiner may precede one or both adjectives. If the second adjective is preceded by a determiner, the reference is more likely to be what Fischer (2012, p. 266-267) terms 'sloppy'; i.e. the adjectives do not refer to the same entity, especially in the A-N-and-A pattern. Fischer only considers Old English, but we can assume that the same is the case in Old Norse, although more work needs to be done here. An Old English example is given in (14), where it is clear that it is not the same citizens that are good and evil. ${ }^{8}$ This has implications for the formal analysis of the phrases, which future work will have to take into account.

pa godan ceastergewaran and ða yfelan
the good citizens and the evil
'the good and the evil citizens'

(cocathom2: 4:38.262.854)

'the good and the evil citizens'

The reference can also be 'strict' in phrases with two determiners, especially with singular head nouns. An example is (15), where the two adjectives refer to the same king. The proportion of strict identity in such phrases is lower than in phrases without a second determiner, but that does not mean that this kind of reference is rare: $46.1 \%$ of Fischer's cases in postnominal and-constructions had strict identity (2012, p. 267). ${ }^{9}$
se strongesta cyning \& se gylpgeornesta, Aðelfrið haten
the mightiest king and the proudest,
Æthelfrith called
'the mightiest and proudest king, called Æthelfrith'
(cobede: 1:18.92.3.838)

It also happens, though not frequently, that the reference is sloppy in constructions without determiners, cf. example (16) from Old Norwegian, where the reference is obviously to different men. For Old English, Fischer (2012, p. 267) reports a proportion of $4.3 \%$ sloppy identity in these constructions. ${ }^{10}$

$$
\begin{aligned}
& \text { gamla menn ok unnga } \\
& \text { old men and young } \\
& \text { 'old and young men' }
\end{aligned}
$$

The N-A-and-A pattern is a relatively rare pattern, especially in Old English (see Table 1), and it is difficult to analyze, since the postnominal position is a busy position in terms of different things that can potentially go on there. I will mention one

8 See Fischer (2012) for a careful analysis of the postposed and-adjective construction.

9 No data is available for the other and-constructions.

10 In addition to 'strict' and 'sloppy', the reference can also be ambiguous. 
analysis problem here. If there is a determiner in front of each adjective $(\mathrm{N}-\mathrm{det}+\mathrm{A}-$ and$\operatorname{det}+\mathrm{A}), \mathrm{YCOE}$ analyzes the adjectives as appositions to the noun, ${ }^{11}$ whereas Menotec analyzes them as attributes. The apposition analysis is obvious in (17), but not in (18), cf. translations, so this illustrates how compromises sometimes have to be made in corpus annotation. An Old Norwegian example is given in (19).

(17) ða twa gecyðnyssa pa ealdan and ða niwan the two testaments the old and the new

'the two testaments, the old and the new' $\quad$ (cocathom2: 12.1:117.258.2549)

(18) Oswald, Norðanhymbra cyning se betsta \& se cristenesta

Oswald, Northumbrians' king the best and the most christian

'Oswald, the best and most Christian Northumbrian king' (cobede: 2:5.110.2.1027)

(19) byrr hinn bazti oc hinn hogazti

(strleik: 101)

sailing wind the best and the timeliest

'the best and most timely sailing wind'

What this brief discussion has made clear is that it is impossible to account for the precise distribution of adjectives, especially in the and-patterns, without carrying out very detailed queries, combined with manual culling of examples. The cross-linguistic aspect, where data is collected from corpora that are annotated on the basis of different theoretical frameworks, makes it particularly challenging to achieve both good recall and good precision (Ball 1994).

A final point to be mentioned is that Old Norwegian has postnominal possessives, as in (20), whereas postnominal possessives are only used in certain specific constructions in Old English, e.g. Fæder ure 'our Father' with reference to God. Differences of this kind may account for the seemingly greater tolerance of Old Norwegian with respect to placing coordinated adjectives postnominally, though it should be kept in mind that the numbers are low in this category.

misgiærningar varar margar ok mycclar
misdeeds our numerous and great
'our numerous and great misdeeds'

To sum up, the categories presented in this section give an overview of the distribution, but we have seen that a number of issues should ideally be taken into account, and that it would be possible, and indeed necessary, to create more fine-grained subcategories for each of the patterns in order to fully understand the workings of Old English and Old Norwegian adjectives. We must, however, leave that to future work;

11 They are thus not analyzed as attributive adjectives. There were seven such instances. 
we will instead focus on the first of the patterns presented above, namely the A-A$\mathrm{N}$ type, and compare Old English and Old Norwegian. But first we make a detour to Wonderland.

\section{Intermezzo: Alice's Adjectives in Wonderland}

From time to time a text is translated from the modern language into its earlier version, and so Lewis Carroll's Alice's Adventures in Wonderland now exists in Old English under the title Æððlgýðe Ellendǽda on Wundorlande thanks to the efforts of Peter Baker (2015).

One challenging aspect of this type of translation is of course the vocabulary and how to render modern concepts, often expressed by means of French or Latin loanwords, into Old English with its predominantly Germanic vocabulary. Another one is syntax, since the syntax of English has changed considerably since Old English times. The dilemma for the translator is therefore to what extent the translation should reflect Old English syntax, and to what extent it should be modernized in order to aid the contemporary reader, who may enjoy reading Old English but does not necessarily have much knowledge about actual Old English syntax or the syntactic variation that characterizes this stage of the language.

For the purposes of this intermezzo, I manually extracted all the noun phrases containing two attributive adjectives (A-A-N) from the first five chapters of Alice. There were 36 instances. Then I compared these to Baker's translation, to see which strategies he had employed. The results are given in Table 2.

\begin{tabular}{lrr}
\hline & $\#$ & $\%$ \\
\hline A-A-N & 15 & 41.7 \\
A-N-and-A & 4 & 11.1 \\
A-and-A-N & 3 & 8.3 \\
A-N & 3 & 8.3 \\
other & 11 & 30.6 \\
\hline Total & 36 & 100.0 \\
\hline
\end{tabular}

Table 2: The translation of present-day English A-A-N noun phrases into Old English in Baker's Æðelgýðe Ellendǽda on Wundorlande

As Table 2 shows, Baker often chooses to translate modern A-A-N order into the same order in Old English, cf. (21)-(23). ${ }^{12}$

(21) the wise little Alice séo wíse lýtle Æðelgýð

12 The page numbers refer to the pages in the editions used: Carroll (1971) and Baker (2015). 
(22) large round eyes (p. 37)

miclum sinewealtum éagum

(23) the distant green leaves pám fyrlenum grénum léafum

Sometimes Baker coordinates the two prenominal adjectives, as in (24), and sometimes he employs the well-known Old English (and Old Norse) pattern of postponing one of the adjectives, i.e. the A-N-and-A pattern, as in (25) (see (10) for authentic examples).

(24) low trembling voice

stillre and bifiendre stemne

(25) shrill passionate voice

sciellre stefne and grambǽrr

It also happens that Baker simply leaves out one of the adjectives, as in (26). All three occurrences of A-N in this little dataset are translations of the little golden key. After having introduced the little golden key, Baker, unlike Carroll, apparently does not find it necessary to specify both little and golden every time.

(26) the little golden key

(p. 14, p. 17)

pá lýtlan cǽge

pá gyldenan cǽge

In the category 'other' are found various other strategies, some of which also involve omission, but in addition to something else. In (27), for example, one adjective has been omitted and the remaining adjective is modified by an adverb, perhaps to strengthen the meaning of ungelæred so that it corresponds to ignorant. In (28) one adjective is omitted and the meaning corresponding to the quantifier several occurs postnominally, and in (29) Baker has perhaps reasoned that it is obvious that a kid's hide is white and therefore left out the adjective. In (30) both adjectives are omitted, while in (31) the head noun is omitted and the adjectives are made predicative. In a prepositional expression is used in (32).

In (30) both adjectives are omitted, while in (31) the head noun is omitted and the adjectives are made predicative. In (32) a prepositional expression is used.

(27) an ignorant little girl

swiðe ungelǽred mǽdencild

(p. 10)

very unlearned maid-child 
(28) several nice little stories

wynsumra spella ná féawa

winsome stories not few

(29) one of the Rabbit's little white kid-gloves

(p. 19-20)

áne pæs Haran lýtelra glófa of ticcenes felle geworhtra (p.20) one of the Rabbit's little gloves of kid's hide made

(30) her eyes immediately met those of a large blue caterpillar

pá sóna lócode héo on sumes tréowwyrmes éagan

then immediately looked she into a tree-worm's eyes

(31) She is such a dear quiet thing

Héo is swá leof and swá smylte

she is so dear and so quiet

(32) A little bright-eyed terrier

Lýtel eorphund mid beorhtum éagum

little earth-hound with bright eyes

If we compare Baker's translation to the data from Old English as presented in Table 1, we see that the three most common Old English patterns are also found in Baker's translation of A-A-N order in Alice. However, the difference between authentic Old English and the translation into Old English is that the authentic language rarely allows two descriptive adjectives in an A-A-N pattern (which is the one Baker employs most frequently in his translation), as section 5 will make clear. Hence, without depreciating Baker's impressive achievement in any way, this little exposition reminds us that element order in the early stages of English is not just about syntactic rules, but that more subtle mechanisms, for example to do with semantics, are also at play.

\section{The Adjective-Adjective-Noun pattern}

We return to the authentic texts. The A-A-N pattern is the most frequent Old English pattern, and the second most frequent Old Norwegian pattern. As regards Old English, Mitchell (1985, §173) comments that "[t]here is room for more work on the arrangements when two attributive adjectives qualify the same noun" without a linking conjunction. He observes that although this pattern seems to be infrequent, it does occur, and hence the claim that Old English adjectives were non-recursive ${ }^{13}$ (Spamer 1979, cited in Mitchell 1985 I, §173) does not hold. Fischer (2000, p. 163), however, points out

13 The term 'recursive' is not well defined in any of the sources mentioned here. It seems that the term is used in a wide, non-theoretical sense, referring to adjectives occurring in a series without coordinating conjunction(s). 
that Spamer's claim relates to strong adjectives only, since Spamer does not regard weak adjectives as adjectives proper, but as so-called 'adjuncts', i.e. elements which behave like the first part of a compound noun (Fischer 2000, p. $177 \mathrm{fn} 8$; Spamer 1979, p. 242,246$)$. Fischer, on the other hand, suggests that neither strong nor weak adjectives are recursive in Old English (2000, p. 171), though she presents some counterexamples for both strong and weak adjectives, which she, interestingly, accounts for in much the same way. She notes that many of them are denominal adjectives referring to material or nationality, or she calls them idiomatic constructions (2000, p. 172-174; see also Fischer 2006, p. 269). Fischer (2001, p. 258) comments that "in Old English adjectives cannot really occur in a row as they do in Present-day English ... In Old English two adjectives are either connected by and or draped around the noun". In Fischer (2006, p. 253), she says that it was unusual for adjectives to be stacked, whereas Fischer and van der Wurff (2006, p. 125) and Fischer (2012, p. 255 fn 4) say that adjectives could not be stacked. Pysz (2007; 2009, p. 29-34, 208-221) takes both Spamer (1979) and Fischer (2000) to task on empirical grounds, and shows that the number of Old English prenominal stacked adjectives, both weak and strong, is non-negligible.

As we saw in Table 1, there are numerous examples of A-A-N in Old English, and the purpose of this study is to have a closer look at what types of adjectives are found in this construction. My hunch, and hence my hypothesis, was that both Old English and Old Norwegian, unlike present-day English and Norwegian, disallow two descriptive adjectives next to each other.

The next step, then, was to study the distribution of adjectives within this pattern. It immediately became clear that in a majority $(186,62.8 \%)$ of the Old English A-A-N constructions, one of the adjectives is agen 'own', ilca 'same', oðer 'other', self 'same', or swilc 'such'. ${ }^{14}$ They are annotated as adjectives because they take adjectival endings, but their degree of 'adjectivity' can be discussed. For our purposes, they can roughly be categorized as peripheral, non-descriptive, determiner-like adjectives, and they easily combine with descriptive adjectives, as in (33) and (34).

(33) se ylca arwyrða wer the same honourable man

(cogregdC: 7.49.20.558)

(34) oðrum langsumum spræcum

(coaelive: 86.1263 ) other lengthy speeches

Another large group $(64,21.6 \%)$ which could be excluded was noun phrases containing classifiers, i.e. adjectives that denote type or origin. In the modern language, such adjectives would typically be found in the prehead position, and are the 'least adjectival and most nominal' of the adjectives (Quirk et al. 1985, p. 1339). Some Old English examples are given in (35)-(38), with the classifiers underlined. The common 
adjective halig 'holy' was also included in this category, although it can co-occur with a classifier (38).

(35) se gooda heofenlica fæder the good heavenly father

(36) pone smyltan suðanwesternan wind the calm southwesterly wind

(37) anne picne linenne clæð a thick linen cloth

(38) pære halgan Romaniscan cirican the holy Roman church (cocathhom1: 18.322.150.3542)

(coboeth: 4.10.10.122)

(coherbar: 130.1.1920)

(cobede: 2.102 .10 .961$)$

When these two largest groups had been accounted for, 46 noun phrases remained, so the procedure of evaluating whether the two adjectives were descriptive or not continued. There was a small group $(6,2.0 \%)$ of noun phrases with quantifier-like adjectives, as in (39) and (40) (see also Old Norwegian below).

(39) mænigfeald gastlic gewin

(coverhom: 41.1789)

manifold spiritual battle

(40) missenlicum pearfendum mannum (cogregdC: 28.159.7.1898) various needy men

The annotation of two of the noun phrases (0.7\%) can be discussed, namely (41) and (42). In (41), unmetlice is annotated as an adjective in YCOE, but Bosworth-Toller considers unmetlice to be an adverb in the same example. In Old English -lic is an adjective suffix. This adjective suffix can be combined with a case ending, so if unmetlice is interpreted as an adjective in (41), $-e$ is the nominative plural feminine strong adjectival ending. Adverbs were usually formed from adjectives, e.g. with the suffix $-e$ or with the suffix -lice. For example, the adjective freondlic 'friendly' becomes the adverb freondlice 'amicably', and the adjective blind 'blind' becomes the adverb blindlice 'blindly'. In other words, in Old English -lice can either signal adjective + case ending, or an adverb made from an adjective in -lic, or an adverb formed with the suffix -lice. This means that unmetlice in (41) could be interpreted as either an adjective or an adverb. In (42), on the other hand, it is likely that inlice is an adverb, since ping is a neuter noun and we would therefore not expect a case ending in - $e$ for the adjective (accusative here). Bosworth-Toller gives the meaning 'thoroughly' in this example, and this fits well with the context.

(41) unmetlice immoderate(ly?) greate heanisse

great heights (coalex: 8.11.45) 
$(42)$

inlice good ping

(coboeth: 34.94.5.1809) inward(ly?)/thorough(ly?) good thing

We are down to 38 noun phrases, and the most difficult classification remains. When I looked at the remaining examples, it became clear that for many of them there is a hierarchical structure within the noun phrase, such that one adjective has scope over the other. According to Fischer and van der Wurff (2006, p. 125), this is not possible in Old English:

It seems to be the case that in $\mathrm{OE}$ each adjective had the same level with respect to the noun; there was no hierarchy in which one adjective modified the remainder of the NP. It was therefore virtually impossible to put one adjective after another in a row.

I will claim that such a hierarchy is indeed possible in Old English, but it is sometimes difficult to determine it with certainty for specific occurrences. For example, in (43), it is clear that the meaning is that the man is poor (in the emotive meaning) because he is childless (he has lost his son to an evil spirit). In (44), the reference is to a young man who is unknown, not a man who is unknown and young. In (45), the base actions are similar to previous base actions. Hence, the first adjective has scope over the other in these cases.

(43) se earma bearnleosa ceorl

(cochdrul: 84.39.1132)

the poor childless churl

(44) an uncuð geong man

(cosevens1: 559.438)

an unknown young man

(45) gelicum fullicum weorcum similar base actions

At the other end of the scale, we find examples such as (46)-(48), which clearly have two asyndetically coordinated adjectives, i.e. two adjectives that separately describe the noun.

(46) Cristes sopre eapmodlicre andetnesse

(coblick: 171.5.2159)

Christ's true humble confession

(47) pæt ofstandende picce slipige horh

(colaece: 16.1.14.2317)

the remaining thick slimy phlegm

(48) pa clænan mildheortan men

(coverhom: 79.2192)

the clean mildhearted men 
But then there are some occurrences for which it is difficult to decide whether the adjectives are hierarchically structured or modify the noun independently of each other. Are the tales in (49) false tales that are old, or old and false tales? Are the men in (50) worthy because they are righteous, or worthy and righteous? Is the lust in (51) independently excessive and unclean or not?

(49) ealdum leasum spellum

(coboeth: 35.98 .25 .1907$)$

old false tales

(50) pa sawla para fullmedomra rihtwisra manna (cogregdC: 26.295.18.4373) the soul of the worthy righteous men

(51) ofermæte unclæne luste

(comart3: Ja17,A.10.126) excessive unclean lust

The final count gave 20 instances of noun phrases in which one of the adjectives had scope over the other, and eight of these involved the adjective earm 'poor'. I found eight examples which clearly had two descriptive adjectives, and ten examples that were uncertain (among them some duplicates). A summary of the findings for Old English is given in Table 3.

\begin{tabular}{lrr}
\hline & $\#$ & $\%$ \\
\hline One adjective is agen, ilca, oðer, self, or swilc & 186 & 62.8 \\
Classifiers & 64 & 21.6 \\
Quantifier-like & 6 & 2.0 \\
Possible misannotations with -lice & 2 & 0.7 \\
One adjective has scope over the other & 20 & 6.8 \\
Uncertain whether one adjective has scope over the other & 10 & 3.4 \\
Two adjectives describing the noun independently of each other & 8 & 2.7 \\
\hline Total & 296 & 100.0 \\
\hline
\end{tabular}

Table 3: Distribution of adjectives in the Old English A-A-N pattern

We now turn to Old Norwegian. Here, the picture is very clear. In a majority of the A-A-N constructions (27, i.e. 52.9\%), the first of the two adjectives is margr 'many, numerous', as in (52). The exception is again Magnus Lagabøte's national law code, in which most of the constructions involve a numeral annotated as an adjective, e.g. (53).

marga fagra viði

(strleik: 1048)

many beautiful trees

(53) xij skynsamer menn

(mll: 659)

twelve reasonable men 
There were also other instances of quantifier-like adjectives, e.g. margskonar 'manifold' in (54) and fyrst in (55). Altogether, the quantifiers (including margr) accounted for 42 of the 51 (82.4\%) A-A-N noun phrases in Old Norwegian.

(54) margskonar goðom drycc

(strleik: 1482)

all-kinds-of good drink

(55) Fyrst licamleg synd

(homiliebok: 632)

first bodily sin

Of the remaining nine phrases, six contained a classifier, as in (56) and (57) (see also (6b) above), and in one, the first adjective had scope over the other (58).

(56) visum boc lærðom man\{n\}um

wise book-learned man

(57) dyrlegr heilagr maðr

(strleik: 1010)

excellent holy man

(58) ó orðenna

goðra luta

(homiliebok: 678)

undone (i.e. unperformed) good things

(homiliebok: 3542)

In the end, only two examples remained of what could be termed two stacked descriptive adjectives, namely (59) and (60).

(59) Sa hinn riki gamle maðr

(strleik: 300)

DET DET rich old man

'the rich old man'

(60) einum hinum bazta rauðum hesti

(strleik: 1740)

DET DET best red horse

'a splendid red horse'

It seems that for both Old English and Old Norwegian, we can conclude that the AA-N pattern is dispreferred for noun phrases with two descriptive adjectives, though in order to evaluate it properly, we would need to consider the other patterns in some detail. It might be that two descriptive adjectives are generally uncommon in noun phrases. However, it is likely that when two adjectives are coordinated by means of and, as in (9)-(11) above, they are also descriptive. 


\section{Conclusion}

This paper has given an empirical overview of adjective position in Old English and Old Norwegian noun phrases containing two attributive adjectives. The different possible patterns were presented, and one of them, the Adjective-Adjective-Noun pattern, was considered in some detail. The hypothesis was that two stacked adjectives are not both descriptive, and this was borne out. There were a few exceptions, but we would not expect syntactically variable languages like Old English and Old Norwegian to be completely consistent, especially since they have both changed with respect to syntax and word order.

\section{Acknowledgements}

I thank two anonymous reviewers and Hildegunn Dirdal for useful comments, Paul Meurer for help in narrowing down the INESS queries for Old Norwegian, Ann Taylor for help with some particularly pesky queries in YCOE, and Helge Dyvik for a discussion of certain points. Search in the Menotec corpus has been made possible through the INESS infrastructure (Rosén et al. 2012), a part of CLARINO (http://clarino.uib.no/iness).

\section{References}

Baker, Peter (2015). Æðelgýðe Ellendǽda on Wundorlande. Portlaoise: Evertype.

Ball, Catherine N. (1994). “Automated Text Analysis: Cautionary Tales." In: Literary \& Linguistic Computing 9.4, pp. 295-302.

Bosworth-Toller Anglo-Saxon Dictionary (online). URL: http://bosworth.ff.cuni.cz. Carroll, Lewis (1971). Alice's Adventures in Wonderland and Through the Looking-glass. Ed. by Roger Lancelyn Green. London/NewYork/Toronto: Oxford University Press. Originally published by Macmillan (1865 and 1871).

Faarlund, Jan Terje (2004). The Syntax of Old Norse. Oxford: Oxford University Press. Faarlund, Jan Terje, Svein Lie, and Jan Ivar Vannebo (1997). Norsk referansegrammatkk. Oslo: Universitetsforlaget.

Fischer, Olga (2000). "The position of the adjective in Old English". In: Generative Theory and Corpus Studies. A Dialogue from 10 ICEHL. Ed. by Ricardo Bermúdez-Otero, David Denison, Richard M. Hogg, and C. B. McCully. Berlin/New York: Mouton de Gruyter, pp. 153-181.

- (2001). "The position of the adjective in (old) English from an iconic perspective". In: The Motivated Sign. Ed. by Olga Fischer and Max Nänny. Iconicity in Language and Literature 2. Amsterdam: John Benjamins, pp. 249-276.

- (2006). "On the position of adjectives in Middle English." In: English Language and Linguistics 10.2, pp. 253-288. 
Fischer, Olga (2012). "The status of the postposed 'and-adjective' construction in Old English: attributive or predicative?” In: Analysing Older English. Cambridge: Cambridge University Press, pp. 251-284.

Fischer, Olga and Wim van der Wurff (2006). "Syntax". In: A History of the English Language. Ed. by Richard Hogg and David Denison. Cambridge: Cambridge University Press, pp. 109-198.

Haugen, Odd Einar (1995). Grunnbok i norrønt språk. Oslo: Gyldendal.

Haumann, Dagmar (2003). "The postnominal 'and adjective' construction in Old English.” In: English Language and Linguistics 14.1, pp. 57-83.

- (2010). "Adnominal adjectives in Old English". In: English Language and Linguistics 14.1, pp. 53-81.

Lass, Roger (2000). "Language periodization and the concept of 'middle". In: Placing Middle English in Context. Ed. by Irma Taavitsainen, Terttu Nevalainen, Päivi Pahta, and Matti Rissanen. Berlin/New York: Mouton de Gruyter, pp. 7-41.

Mitchell, Bruce (1985). Old English Syntax. Vol. 1. Oxford: Oxford University Press.

Nygaard, Marius (1906). Norrøn syntax. Kristiania: Aschehoug.

Pysz, Agnieszka (2007). "The (im)possibility of stacking adjectives in Early English". In: Bells Chiming from the Past: Cultural and Linguistic Studies on Early English. Ed. by Isabel Moskowich-Spiegel and Begoña Grespo-García. New York/Amsterdam: Rodopi, pp. 15-35.

- (2009). The Syntax of Prenominal and Postnominal Adjectives in Old English. Newcastle upon Tyne: Cambridge Scholars Publishing.

Quirk, Randolph, Sidney Greenbaum, Geoffrey Leech, and Jan Svartvik. (1985). A Comprehensive Grammar of the English Language. London/New York: Longman.

Ringdal, Karl (1918). Om det attribute adjektivs position i oldnorsk prosa. Kristiania: Aschehoug.

Rosén, Victoria, Koenraad De Smedt, Paul Meurer, and Helge Dyvik (2012). “An Open Infrastructure for Advanced Treebanking”. In: META-RESEARCH Workshop on Advanced Treebanking at LREC2012. Ed. by Jan Hajič, Koenraad De Smedt, Marko Tadić, and António Branco. Istanbul, Turkey, pp. 22-29.

Spamer, James B. (1979). "The development of the definite article in English: A case study of syntactic change”. In: Glossa 13.2, pp. 241-250.

Taylor, Ann, Anthony Warner, Susan Pintzuk, and Frank Beths (2003). The YorkToronto-Helsinki Parsed Corpus of Old English Prose (YCOE). uRL: http : / / www users.york.ac.uk/ lang22/YcoeHome1.htm.

The Menotec corpus of Old Norwegian (online). URL: http://www.menota.org/menotec. xml.

Valfells, Sigrid and James E. Cathey (1981). Old Icelandic. An Introductory Course. Oxford: Oxford University Press. 